\title{
MODEL PENGUATAN LITERASI DIGITAL MELALUI PEMANFAATAN E-LEARNING
}

\author{
Rila Setyaningsih ${ }^{1}$, Abdullah $^{2}$, Edy Prihantoro ${ }^{3}$, Hustinawaty ${ }^{4}$
}

\author{
Universitas Darussalam Gontor ${ }^{1,2}$ Universitas Gunadarma ${ }^{3,4}$ \\ 1,2J1. Raya Siman, Km.06, Siman, Ponorogo, Índonesia, 63471, Telp. (0352) 483762 \\ 3,4Jl. Margonda Raya No. 427, Pondok Cina, Beji, Kota Depok, Jawa Barat. 16424 \\ Email : rilasetya@unida.gontor.ac.id ${ }^{1}$
}

\begin{abstract}
This study aims to find a model for strengthening digital literacy at the University of Darussalam Gontor. This research uses descriptive qualitative method. Data are collected through observation and interviews with five lecturers in the Communication Study Program at the University of Darussalam Gontor. This research found a model of strengthening digital literacy through the use of e-learning. The model includes elements of communication and collaboration in the form of active participation in learning and research activities. It consists of individual competence components in the form of use skills, critical understanding, and communicative abilities. This research contributes to a model of strengthening digital literacy through the use of e-learning.
\end{abstract}

Keywords: model, digital literacy, communication and collaboration, e-learning

\begin{abstract}
Abstrak
Penelitian ini bertujuan untuk menemukan model penguatan literasi digital di Universitas Darussalam Gontor. Penelitian ini menggunakan metode deskriptif kualitatif. Data dikumpulkan melalui observasi dan wawancara dengan lima dosen di Program Studi Komunikasi di Universitas Darussalam Gontor. Penelitian ini menemukan model penguatan literasi digital melalui penggunaan e-learning. Model ini mencakup unsur-unsur komunikasi dan kolaborasi dalam bentuk partisipasi aktif dalam kegiatan pembelajaran dan penelitian. Ini terdiri dari komponen kompetensi individu dalam bentuk keterampilan penggunaan, pemahaman kritis, dan kemampuan komunikatif. Penelitian ini berkontribusi pada model penguatan literasi digital melalui penggunaan e-learning.
\end{abstract}

Kata kunci : model, literasi digital, communication and collaboration, e-learning

\section{Pendahuluan}

Di era revolusi keempat yang dikenal dengan revolusi digital, semua informasi dapat diperoleh dengan real-time dan cepat dimana saja dan kapan saja. Adanya mesin pencari membantu seseorang mencari bahan rujukan yang diinginkannya secara cepat dengan pembiayaan rendah. Hal ini karena bahan ajar dan aktvitas interaksi telah terdigitalisasi oleh kemajuan teknologi. Friedman (Afandi, Junanto, \& Afriani, 2016) mengilustrasikan perubahan ini sebagai "the world is flat" - yang merujuk pada sebuah keadaan dimana dunia tidak terbatas pada batas-batas negara dan zona waktu karena perkembangan teknologi. Perkembangan teknologi informasi telah menciptakan sebuah "ruang baru" yang bersifat artifisial dan maya, yang disebut cyberspace (Piliang, 2012).

Perkembangan teknologi informasi direspon dengan adanya penetrasi dan perilaku penggunaan internet Indonesia yang mengalami pertumbuhan dari tahun ke tahun. Hasil survey APJII (Asosisasi Penyelenggara Jasa Internet Indonesia) menyebutkan bahwa terdapat peningkatan pengguna internet di Indonesia sebanyak 


\section{INFOGRAFIS HASIL SURVEY 2016}

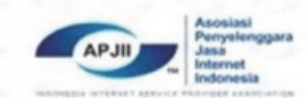

STATISTIK PENGGUNA INTERNET INDONESIA

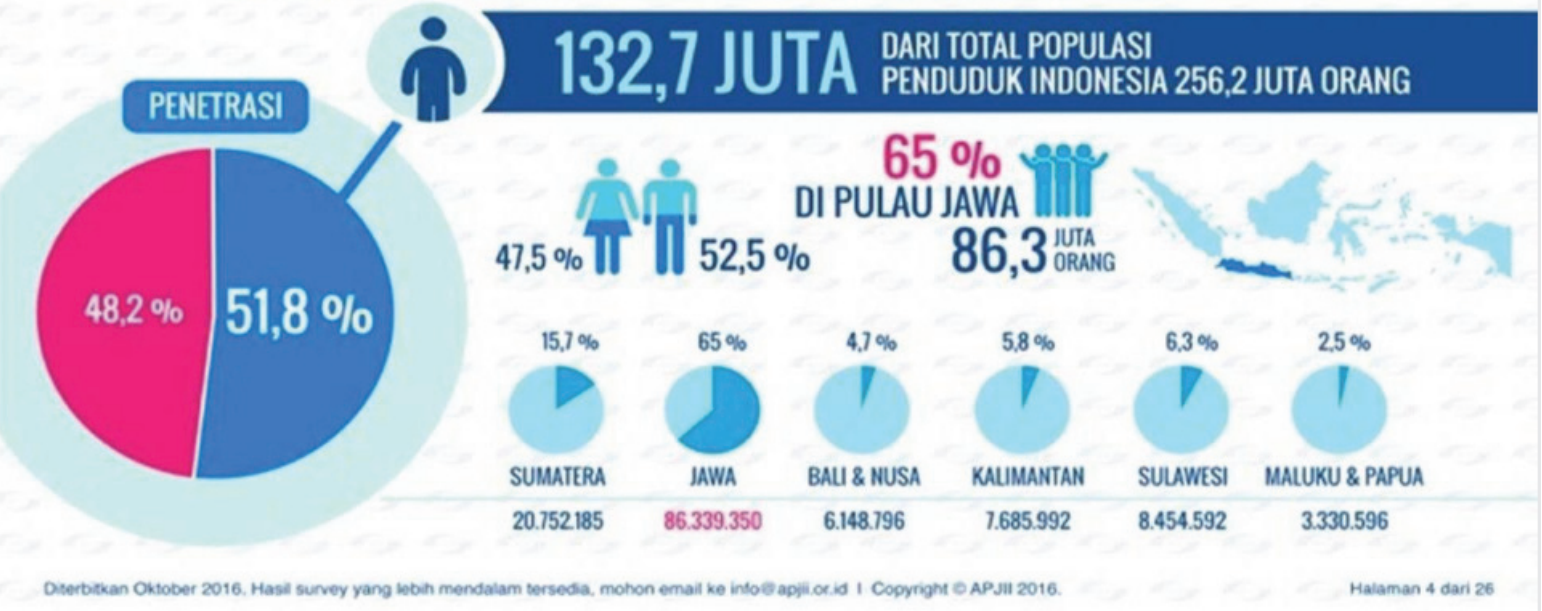

Gambar 1. Statistik Pengguna Internet Indonesia Sumber: Buletin APJII (2016:1)

132,7 juta jiwa di tahun 2016 menjadi 143,26 juta jiwa pada tahun 2017, atau setara dengan 54,7 persen dari total populasi penduduk Indonesia (Indonesia, 2016). Gambar 1 merupakan hasil survei tahun 2016 yang dilakukan oleh APJII (Asosiasi Penyelenggara Jasa Internet Indonesia) menunjukkan bahwa 51,8\% yakni sebanyak 132,7 juta orang dari total populasi penduduk Indonesia sebanyak 256, 2 juta orang adalah pengguna internet. Sebanyak $65 \%$ pengguna internet di Indonesia adalah penduduk di Pulau Jawa dengan jumlah 86,3 juta orang.

Perkembangan teknologi informasi menjadi bagian dari munculnya era revolusi digital di Indonesia. Perkembangannya yang sangat pesat mampu memberikan pengaruh besar dan mendominasi seluruh sektor kehidupan masyarakat, termasuk di dunia pendidikan. Tuntutan akademik pada tiap jenjang pendidikan di Indonesia berbedabeda (Akbar \& Dina, 2017). Digital-age dalam dunia pendidikan, khususnya pada pendidikan tinggi, memiliki konsekuensi berupa desain pembelajaran dengan memanfaatkan media digital sebagai sarana untuk meningkatkan pengetahuan mahasiswa. Media digital dapat menyajikan materi pembelajaran secara kontekstual, audio maupun visual secara menarik dan interaktif (Umam, Kaiful; Zaini, 2013). Universitas pesantren sebagai bagian dari lembaga pendidikan tinggi sudah selayaknya menyesuaikan diri untuk menyelenggarakan proses pembelajaran berbasis digital.

Kemajuan teknologi informasi dan internet saat ini mengakibatkan sumber daya informasi digital sangat melimpah (Kurnianingsih, Rosini, \& Ismayati, 2017: 62). Di sisi lain, perkembangan teknologi informasi diibaratkan seperti dua sisi mata uang yang memberikan efek positif dan negatif kepada masyarakat. Pembelajaran literasi digital tidak bisa dielakkan lagi 
(Anggraini, 2016). Tuntutan inilah yang kemudian melahirkan sebuah pemikiran tentang pentingnya literasi digital, termasuk juga dalam dunia pendidikan. Pesantren saat ini sedang mengalami "kesenjangan budaya" (Adib, 2013). Kemunculan perkembangan teknologi menjadi sebuah tantangan barubagi model pengajaran di pesantren. Lembaga pendidikan pesantren yang telah sejak lama menerapkan model pendidikan tekstual dengan mempelajari kitab-kitab dengan model sorogan, kini menghadapi tantangan baru di era digital. Sorogan adalah metode santri membaca sendiri materi pelajaran kitab di hadapan guru (Maksum, 2016). Kondisi ini menuntut lembaga pendidikan pesantren khususnya perguruan tinggi pesantren untuk menyesuaikan diri. Munculnya era digital juga menjadi tantangan sekaligus peluang bagi para dosen di perguruan tinggi pesantren untuk melakukan inovasi dalam kegiatan pembelajaran. Dosen di perguruan tinggi pesantren dituntut untuk memiliki kemampuan literasi digital.

Berdasarkan hasil observasi diketahui bahwa Program Studi Ilmu Komunikasi Universitas Darussalam Gontor sebagai sebuah pendidikan tinggi berbasis pesantren modern berdiri pada tahun 2014. Sejak saat itu kegiatan pembelajaran masih dominan dengan model tekstual dengan penggunaan buku cetak. Pemanfaatan media digital dalam proses pembelajaran masih sangat terbatas. Disisi lain pendidikan abad 21 menuntut lembaga pendidikan untuk responsif terhadap perkembangan dan perubahan zaman dengan cara menguasai teknologi informasi atau disebut dengan digital-age literacy.
Penyesuaian diri perguruan tinggi dalam penggunaan media digital pada proses pembelajaran menjadi hal yang urgen, termasuk juga di Universitas Darussalam Gontor. Ada beberapa penelitian yang sudah dilakukan dengan fokus literasi digital dan pemanfaatan ICT (Information, Communication and Technology) dalam dunia pendidikan khususnya tentang pemanfaatan e-learning. Pada tahun 2012 Yazdi menulis artikel tentang e-learning sebagai media pembelajaran interaktif berbasis teknologi informasi. Hasil penelitian menunjukkan bahwa produk akhir pembelajaran e-learning diharapkan menjadi aplikasi pembelajaran berbasis teknologi informasi (Yazdi, 2012). Penelitian tentang e-learning juga pernah dilakukan oleh Chandrawati tentang pemanfaatan e-learning dalam pembelajaran. Hasil penelitian menunjukkan bahwa pengembangan e-learning ada tiga kemungkinan dalam sistem pembelajaran berbasis internet, yaitu web course, web centric course, dan web enhanced course (Chandrawati, 2010). Disamping itu, Afandi, Junianto, dan Afriani menulis sebuah artikel ilmiah tentang literasi di era digital (Afandi et al., 2016). Kesimpulan dalam artikel tersebut menjelaskan bahwa merujuk pada dokumen yang diterbitkan enGauge 21st century skill terdapat 4 domain pokok, salah satunya adalah domain Digital-Age Literacy yang terdiri dari delapan aspek, yakni dasar, ilmiah, informasi, visual, teknologi, dan literasi multikultural serta kesadaran global. Penelitian lainnya dilakukan oleh Wijaya, Sudjimat, dan Nyoto (2016). Penelitian ini 
berusaha untuk menggali kompetensi abad 21 yang dibutuhkan oleh industri dan dunia kerja. Hasil penelitian menunjukkan bahwa kemampuan abad ke-21 yang dibutuhkan di dunia usaha dan dunia industri adalah: (1) keterampilan dan belajar berinovasi; (2) kehidupan dan karir; dan (3) keterampilan teknologi dan media informasi (Wijaya, Sudjimat, \& Nyoto, 2016).

Sejalan dengan keempat penelitian tersebut, penelitian ini berusaha untuk menggali lebih jauh tentang pemanfaatan media digital yang mampu menjadi kekuatan untuk meningkatkan kemampuan literasi digital dalam dunia pendidikan. Literasi digital di perguruan tinggi dapat dilakukan dengan langkah communication and collaboration berupa partisipasi aktif dalam jaringan digital untuk pembelajaran dan penelitian. Lebih jauh, penelitian ini berusaha untuk menemukan sebuah model penguatan literasi digital yang dilakukan di perguruan tinggi berbasis pesantren.

Literasi digital adalah ketertarikan, sikap dan kemampuan individu dalam menggunakan teknologi digital dan alat komunikasi untuk mengakses, mengelola, mengintegrasikan, menganalisis dan mengevaluasi informasi, membangun pengetahuan baru, membuat dan berkomunikasi dengan orang lain agar dapat berpartisipasi secara efektif dalam masyarakat. Dalam konsepsi Potter (Widyastuti, Nuswantoro, \& Sidhi, 2016), usaha untuk meliterasi masyarakat berbasis digital bukan sekedar mengenalkan media digital tetapi juga menyinergikan kegiatan sehari-hari yang berujung pada peningkatan produktivitas. Menurut Sholihah literasi digital adalah upaya untuk menemukan, menggunakan maupun menyebarluaskan informasi secara efektif (Sholihah, 2016). Media digital merupakan jenis gawai dalam new media. Menurut Dennis McQuail ada empat jenis media baru, yaitu media komunikasi antarpribadi misalnya email, media permainan yang bersifat interaktif contohnya game, media pencari data atau informasi misalnya search engine di internet, dan media yang bersifat partisipasi, misalnya chatting di internet. Dalam penelitian ini yang dimaksud dengan literasi media digital adalah kemampuan dan keahlian seorang individu dalam memanfaatkan perangkat komputer, internet, dan alat-alat digital lainnya sebagai sarana penunjang aktivitas komunikasi secara optimal.

Banyak model keterampilan yang bermanfaat untuk meningkatkan kemampuan seseorang dan kadang disebut sebagai multi literasi (Mardina, 2011). Menurut NCREL \& Metiri Group kemampuan literasi adalah kecakapan yang menekankan pada kemampuan literasi yang terkoneksi satu dengan lainnya di era digital, tidak saja terbatas pada kemampuan membaca, mendengar, menulis dan berbicara secara lisan (Burkhardt et al., 2003). Literasi digital yang juga dikenal dengan literasi komputer adalah keahlian dalam menggunakan perangkat komputer, internet, dan alat-alat digital lainnya. Literasi digital merupakan upaya to know, to search, to understand, to analyze, dan to use teknologi digital. Beetham, Littlejohn dan McGill menyebutkan ada tujuh elemen literasi digital (JISC, 2017), sebagaimana diilustrasikan dalam gambar 2 . 


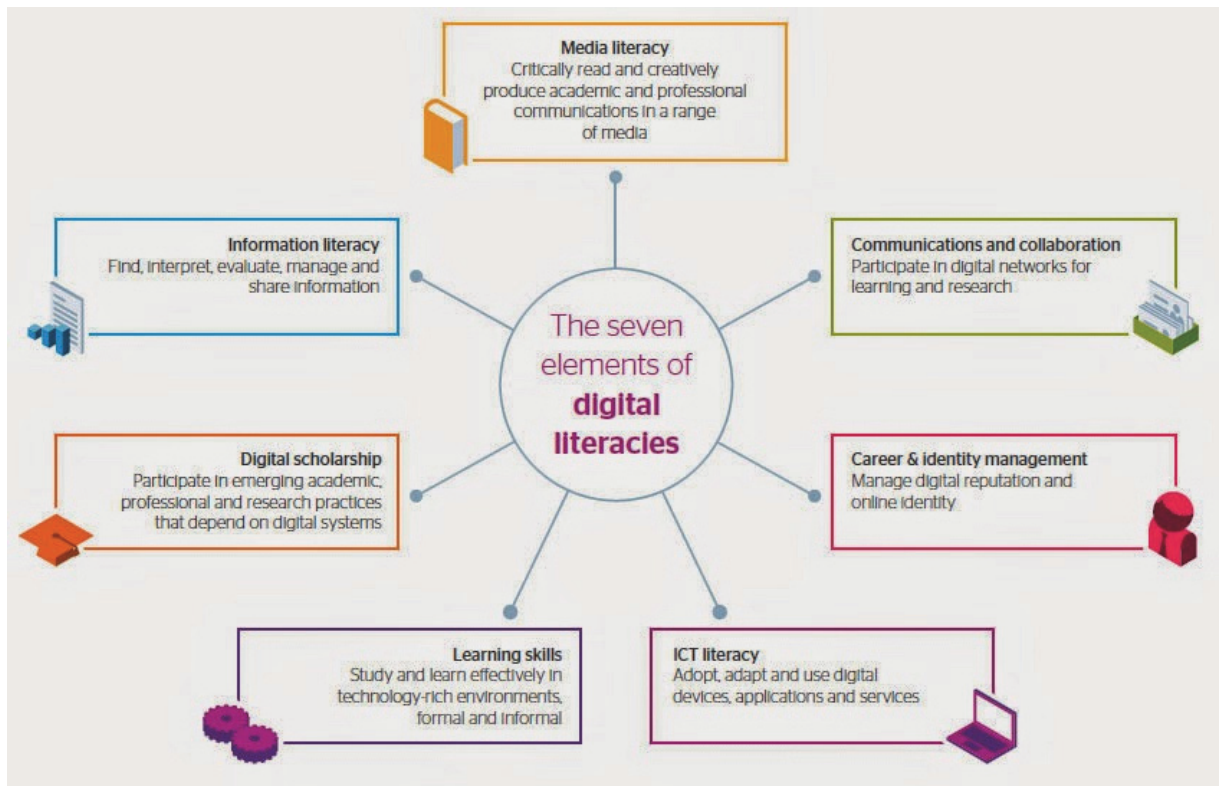

Gambar 2. Elemen Literasi Digital

(Sumber: JISC, 2017)

Tujuh elemen literasi digital tersebut meliputi: (1) Information literacy adalah kemampuan mencari, mengevaluasi dan menggunakan informasi yang dibutuhkan secara efektif (Hasugian, 2008), (2) Digital scholarship adalah elemen yang mencakup partisipasi aktif pengguna media digital dalam kegiatan akademik untuk menjadikan informasi dari media digital tersebut sebagai referensi data, misalnya pada praktik penelitian atau penyelesaian tugas kuliah (Stefani, 2017), (3) Learning skills merupakan belajar secara efektif berbagai teknologi yang mempunya fitur-fitur lengkap untuk aktivitas pembelajaran formal maupun informal,(4)ICT literacy atau disebut dengan melek teknologi informasi dan komunikasi yang fokus pada cara-cara untuk mengadopsi, menyesuaikan dan menggunakan perangkat digital dan media berbasis TIK baik aplikasi dan layananya. Media berbasis TIK yang dimaksud misalnya komputer atau LCD proyektor/power point yang telah didesain/dirancang sedemikian rupa agar dapat dimanfaatkan sesuai dengan pemahamannya, apalagi sudah terkoneksi dengan internet sebagai basis pembelajarannya (Budhirianto, 2016), (5) Career and identy management berkaitan dengan cara-cara mengelola identitas online. Identitas seseorang dapat diwakili oleh sejumlah avatar berbeda yang mampu melakukan hubungan dengan lebih dari satu pihak dalam waktu yang hampir bersamaan (Damayanti, Maria Nala; Yuwono, 2013), (6) Communication and collaboration merupakan bentuk partisipasi secara aktif untuk pembelajaran dan penelitian melalui jaringan digital, dan (7) Media literacy atau literasi media mencakup kemampuan kritis membaca dan kreatif komunikasi akademik dan profesional dalam berbagai media. Adanya literasi media membuat khalayak tidak mudah terperdaya oleh informasiinformasi yang secara sekilas memenuhi dan memuaskan kebutuhan psikologis dan sosialnya (Rianto, 2016). 
Elemen communication and collaboration menjadi fokus dalam penelitian ini. Communication and collaboration sebagai bagian dari elemen literasi digital memiliki pengertian bahwa adanya partisipasi aktif dalam jaringan digital untuk pembelajaran dan penelitian. Sedangkan menurut Stefani, communication and collaboration merupakan partisipasi aktif pengguna media digital untuk mengefisienkan waktu, hal ini erat kaitannya dengan media sebagai digital yang memiliki konvergensi (Stefani, 2017). Communication and collaboration memiliki komponen individual competence yang terdiri dari use skill yang merupakan kemampuan untuk mengakses dan mengoperasikan media, critical understanding berupa kemampuan untuk menganalisis dan mengevaluasi konten media secarakomprehensifdan communicative abilities yaitu kemampuan komunikasi dan partisipasi melalui media (Commission \& Unit, 2009).

Penelitian ini penting dilakukan untuk menemukan model penguatan literasi digital di Universitas Darussalam Gontor. Hal ini mendukung kebijakan Kementerian Komunikasi dan Informatika Republik Indonesia yang disampaikan dalam Siaran Pers No. 181/HM/KOMINFO/08/2018 tanggal 16 Agustus 2018 tentang Literasi Digital Siapkan SDM Unggul dan Cerdas di Era Revolusi Industri 4.0 (Kementerian Komunikasi dan Informatika Republik Indonesia, 2018). Guna mendukung kebijakan pemerintah tersebut penelitian ini bertujuan untuk menemukan model penguatan literasi digital di Universitas Darussalam Gontor.

\section{Metode Penelitian}

Penelitian ini menggunakan metode deskriptif kualitatif untuk menemukan model penguatan literasi digital yang dilakukan Universitas Darussalam Gontor dalam proses pembelajaran. Data dalam penelitian ini diperoleh melalui observasi secara langsung serta wawancara mendalam. Observasi dilakukan dengan melakukan pengamatan secara langsung kegiatan dosen pengampu mata kuliah dasar dalam aktivitas upload materi pembelajaran pada portal e-learning, penyusunan soal pre-test dan post test, serta pembuatan forum diskusi dan pemberian skor pada tugas mahasiswa melalui website e-learning. Wawancara dilakukan dengan dosen-dosen di Program Studi Ilmu Komunikasi UNIDA Gontor yang terdiri dari 5 orang pengampu mata kuliah dasar (Pengantar Ilmu Komunikasi, Teori Komunikasi, Psikologi Komunikasi, Komunikasi Kontekstual, dan Komunikasi Massa). Wawancara dilakukakan secara mendalam tentang komponen kompetensi individual yang terdiri dari penggunaan keterampilan, pemahaman kritis, dan kemampuan komunikatif.

$$
\text { Setelah melakukan observasi }
$$

dan wawancara mendalam, peneliti mengonstruksi pesan-pesan yang diperoleh dari informan dan memetakan pemanfaatan e-learning sebagai bentuk literasi digital khususnya elemen communication and collaboration berupa partisipasi aktif dalam jaringan digital untuk kegiatan pembelajaran. Teknik analisis data dilakukan berdasarkan teori Miles dan Huberman, ada tiga proses tahapan dalam analisa data (1) reduksi 
data, (2) display data, dan (3) konklusi data menurut interpretasi peneliti (Tamin, 2011). Reduksi dilakukan dengan cara merangkum, memilih hal-hal yang pokok, dan memfokuskan pada hal-hal yang penting. Penyajian data dalam bentuk uraian singkat, bagan, hubungan antar kategori, flowchart dan sejenisnya. Penarikan kesimpulan/ verifikasi merupakan alur ketiga dalam teknik analisis data setelah reduksi dan penyajian data. Keabsahan data penelitian dilakukan dengan triangulasi. Triangulasi adalah suatu cara mendapatkan data yang benarbenar absah dengan menggunakan metode ganda (Bachri, 2010). Teknik pengumpulan data yang bersifat menggabungkan dari berbagai teknik dan sumber data yang ada. Triangulasi data dalam penelitian ini adalah triangulasi metode yang dilakukan dengan cara menggabungkan teknik observasi dan wawancara, dan menggabungkan sumber data dari beberapa subjek penelitian.

\section{Hasil Penelitian dan Pembahasan}

Penelitian ini menemukan model penguatan literasi digital di Universitas Darussalam Gontor. Communication and collaboration sebagai salah satu elemen literasi digital dalam penelitian ini berupa pengembangan konten pembelajaran dengan memanfaatkan portal e-learning. Mata kuliah yang menggunakan e-learning terdiri dari Pengantar Ilmu Komunikasi, Teori Komunikasi, Psikologi Komunikasi, Komunikasi Massa, dan Komunikasi Kontekstual.

Untuk mengetahui kemampuan literasi digital pengampu mata kuliah dasar Prodi Ilmu Komunikasi UNIDA Gontor, terbagi kedalam tiga kategori yaitu keterampilan (use skill), pemahaman kritis (critical understanding), dan kemampuan komunikatif (communicative abilities). Kemampuan individual pengampu mata kuliah dasar di Prodi Ilmu Komunikasi Universitas Darussalam Gontor disajikan dalam tabel 1:

Tabel 1. Individul Competence Pengampu Mata Kuliah Dasar Ilmu Komunikasi UNIDA Gontor

\begin{tabular}{|c|c|c|c|}
\hline No. & Kategori Individual Competence & Level & Indikator \\
\hline 1. & Use Skill & Medium & $\begin{array}{l}\text { Subjek penelitian mampu menggunakan media } \\
\text { digital, dan masih dalam proses adaptasi } \\
\text { penggunaan e-learning. }\end{array}$ \\
\hline 2. & Critical Understanding & Medium & $\begin{array}{l}\text { Subjek penelitian mampu memahami konten, } \\
\text { fungsi, dan regulasi penggunaan media digital, } \\
\text { tetapi kemauan croscek informasi kurang. }\end{array}$ \\
\hline 3. & Communicative abilities & Basic & $\begin{array}{l}\text { Subjek penelitian belum mampu melakukan } \\
\text { komunikasi dan partisipasi aktif dalam e-lerning } \\
\text { karena baru pada tahap upload konten dan belum } \\
\text { implementasi ke dalam proses pembelajaran } \\
\text { bersama mahasiswa. }\end{array}$ \\
\hline
\end{tabular}

Tabel 2. Level of Competence

\begin{tabular}{ll}
\hline Level & \multicolumn{1}{c}{ Definisi } \\
\hline \multirow{3}{*}{ Basic } & Individu memiliki seperangkat kemampuan yang memungkinkan penggunaan dasar \\
& media. Terdapat penggunaan media yang terbatas. Pengguna mengetahui fungsi dasarnya, \\
& menggunakannya untuk tujuan spesifik dan untuk menentukan alat. Kapasitas pengguna \\
& untuk menganalisis secara kritis informasi yang diterima masih terbatas.
\end{tabular}




\begin{tabular}{|c|c|}
\hline Level & Definisi \\
\hline Medium & $\begin{array}{l}\text { Kemampuan komunikatif individu melalui media juga terbatas. Individu fasih dalam } \\
\text { penggunaan media, mengetahui fungsinya dan mampu mengoperasikannya, lebih kompleks. } \\
\text { Penggunaan media diperluas. Pengguna mengetahui bagaimana cara mendapatkan dan } \\
\text { menilai informasi yang dia butuhkan, jugamengevaluasi (dan meningkatkan) strategi } \\
\text { pencarian informasi. }\end{array}$ \\
\hline Advanced & $\begin{array}{l}\text { Individu sangat aktif dalam penggunaan media, sadar dan tertarik terhadap hukum yang } \\
\text { memengaruhi penggunaannya. Pengguna memiliki pengetahuan mendalam tentangteknik } \\
\text { dan bahasa dan dapat menganalisis (dan, akhirnya) mengubah kondisi yang mempengaruhi } \\
\text { hubungan komunikatifnya dan penciptaanpesan. Di bidang sosial, pengguna mampu } \\
\text { mengaktifkan kerja samakelompok yang memungkinkan dia untuk menyelesaikan masalah. }\end{array}$ \\
\hline
\end{tabular}

Sumber: European Commission Directorate General Information Society and Media; Media Literacy Unit, 2009

Data yang disajikan pada tabel 2 merupakan level kompetensi yang merujuk pada tingkat kemampuan literasi digital European Commission Directorate General Information Society and Media (2009).

Terdapat tiga kriteria dalam menguatkan kemampuan literasi digital melalui pemanfaatan e-learning di Universitas Darussalam Gontor. E-learning adalah sistem pembelajaran yang diadaptasikan dari sistem yang ada di lembaga pendidikan konvensional ke dalam sebuah sistem digital melalui internet (Susanti \& Sholeh, 2008). E-learning dalam pembelajaran berfungsi sebagai suplemen yang sifatnya pilihan, komplemen (pelengkap), atau subtitusi (Chandrawati, 2010).

Kriteria literasi digital yang pertama adalah use skill. Use skill merupakan keahlian dalam aktivitas akses dan pengoperasian media. Use skill memiliki tiga kriteria, yaitu keahlian dalam penggunaan media secara standar (rendah), keahlian secara aktif dalam penggunaan media, dan keahlian yang tinggi menggunakan dan memanfaatkan media. Indikator keterampilan atau use skill khususnya pada pemanfaatan komputer dan akses internet terdiri dari kepemilikan komputer/laptop; penggunaan komputer/ laptop; kepemilikan akun media sosial dan e-mail; situs yang sering dikunjungi; download dan upload.

Peneliti melakukan observasi secara langsung dengan melihat dan mengamati kegiatan unggah konten pembelajaran ke portal e-learning oleh dosen Prodi Ilmu Komunikasi UNIDA Gontor. Peneliti melakukan pengamatan kegiatan upload konten pembelajaran yang terdiri dari materidalam pembelajaran, soal tes awal dan post-test, dan melakukan create forum diskusi melalui e-learning. Berdasarkan hasil observasi awal sebelum ada e-learning, ditemukan bahwa subjek penelitian yakni dosen-dosen program studi Ilmu Komunikasi Universitas Darussalam Gontor sudah mampu menggunakan dan memanfaatkan media dalam proses pembelajaran. Bentuk pemanfaatan media juga bervariasi, ada yang memanfaatkan media digital dengan menggunakan laptop sebagai alat untuk presentasi materi kuliah kepada mahasiswa, internet sebagai sumber informasi dalam penggalian informasi terkait materi perkuliahan (download), pemanfaatan media sosial berupa grup Whatsapp sebagai sarana 
diskusi perkuliahan di luar kelas dan e-mail untuk pengumpulan tugas mahasiswa. Ada juga yang memanfaatkan Youtube sebagai media untuk mengunggah tugas mahasiswa untuk diberi penilaian. Beberapa subjek masih lebih memilih menggunakan metode ceramah sebagai bentuk pembelajaran di kelas. Buku masih menjadi rujukan utama dalam penyusunan materi pembelajaran. Ini sebagaimana disampaikan oleh salah satu subjek penelitian.

"Pada topik tertentu saya menyampaikan materi dengan metode ceramah, misalnya terkait dengan teori komunikasi maka ceramah dan penggunaan buku sebagai rujukan lebih tepat dilakukan, meskipun pada topik yang lain, studi kasus misalnya, bisa digunakan dengan memanfatkan media pembelajaran lainnya." (subjek 1, wawancara 17 Juli 2018).

Pada tahun 2018, Program Studi Ilmu Komunikasi UNIDA Gontor mengembangkan e-learning sebagai media pembelajaran yang mampu mengakomodir konsep pembelajaran virtual secara lengkap. Dalam e-learning yang dikembangkan terdapat konten materi, soal kuis, dan juga forum sebagai media diskusi antara dosen dengan para mahasiswa. Dengan adanya e-learning materi pembelajaran dosen dapat terdokumentasi dengan lebih baik. E-learning akan sangat membantu meningkatkan level use skill literasi digital para dosen dikarenakan kegiatan pembelajaran dapat dilakukan secara virtual dengan memanfaatkan media digital.

Hal ini senada dengan penelitian yang dilakukan Trilling \& Fadel yang menyatakan bahwa di abad 21 pendidikan harus senantiasa bergerak sejalan dengan kemajuan zaman (Trilling \& Fadel, 2009). Pergerakan ini didasarkan pada perubahan paradigma pendidikan dari yang bersifat konvensional menuju pendidikan abad modern. Pergeseran paradigma dalam pendidikan dapat dilihat pada tabel 3.

Tabel 3. Perbedaan Paradigma Pendidikan Lamadan Paradigma Baru Pendidikan Tinggi

\begin{tabular}{|c|c|}
\hline Paradigma Lama Pendidikan Tinggi & Paradigma Baru PendidikanTinggi \\
\hline Mata kuliah sesuai yang diberikan & Memilih mata kuliah sesuai keinginan \\
\hline $\begin{array}{l}\text { Registrasi dan kegiatan akademik sangat tergantung } \\
\text { pada kalender akademik }\end{array}$ & $\begin{array}{l}\text { Registrasi dan kegiatan akademik terbuka sepanjang } \\
\text { tahun }\end{array}$ \\
\hline Universitas berada pada lokasi tertentu & Universitas bersifat maya \\
\hline Lama kuliah dibatasi perolehan gelar & Belajar sepanjang hayat \\
\hline Umur berkisar 18-25 tahun & Umur mulai 18 tahun sampai tak terbatas \\
\hline Tergantung pada kegiatan institusinya & Tergantung penilaian pasar \\
\hline Keluaran/produknya bersifat tunggal & Informasi yang diperoleh dapat digunakan ulang \\
\hline Mahasiswa diperlakukan sebagai objek & Mahasiswa dianggap sebagai konsumen \\
\hline Pembelajaran dilakukan di dalam kelas & Pembelajaran dapat dilakukan dimanapun juga \\
\hline Bersifat multikultur & Bersifat global \\
\hline Konsepnya merupakan satu kesatuan besar & Konsepnya kecil dan terpilah-pilah \\
\hline Single discipline & Multi-disiplin \\
\hline Terfokus pada institusi & Terfokus pada pasar \\
\hline Dibiayai pemerintah & Dibiayai melalui dana masyarakat \\
\hline Terknologi merupakan investasi yang mahal & Teknologi sebagai unsur pembeda \\
\hline
\end{tabular}

Sumber : (Darmayanti, Setiani, \& Oetojo, 2007) 
Tabel 3 menunjukkan bahwa pentingnya suatu konsep dan mekanisme pembelajaran berbasis teknologi informasi yang kemudian dikenal dengan istilah e-learning. Hal ini membawa pengaruh terjadinya proses transformasi pendidikan konvensional ke dalam bentuk digital. Tranformasi ini mendorong peningkatan kemampuan digital dan terjadi per geseran model pembelajaran tekstual menuju kontekstual. Pembelajaran kontekstual merupakan konsep belajar yang membantu pendidik/pengajar mengaitkan antara materi yang diajarkannya dengan situasi dunia nyata peserta didik dan mendorong peserta didik membuat hubungan antara pengetahuan yang dimilikinya dengan penerapannya dalam kehidupan mereka sebagai anggota keluarga dan masyarakat (Sulianto, 2011). Perguruan tinggi dituntut untuk menggunakan paradigma baru dalam pembelajaran sehingga dapat menghasilkan output yang maksimal.
Penelitian ini juga senada dengan penelitian Wijaya, Sudjimat, dan Nyoto tentang transformasi pendidikan abad 21 (Wijaya et al., 2016). Terdapat pergeseran paradigma belajar abad 21 sebagaimana gambar 3 .

Kategori Individual Competence yang kedua adalah Critical Understanding atau pemahaman kritis, adalah kecakapan dalam melakukan analisis dan evaluasi isi media secara luas dan lengkap. Kriteria pemahaman kritis ini meliputi: kecakapan untuk memahami isi dan fungsi media, mempunyai pengetahuan tentang media dan aturan atau regulasi media, dan perilaku pengguna media dalam memanfaatkan media. Kriteria pemahaman kritis meliputi kepercayaan informan terhadap media massa atau internet; mampu membedakan kebenaran konten situs berita; kemampuan memahami regulasi pemerintah terkait media; dan melakukan cek sumber berita.

\section{Skema 1. Pergeseran Paradigma Belajar Abad 21}
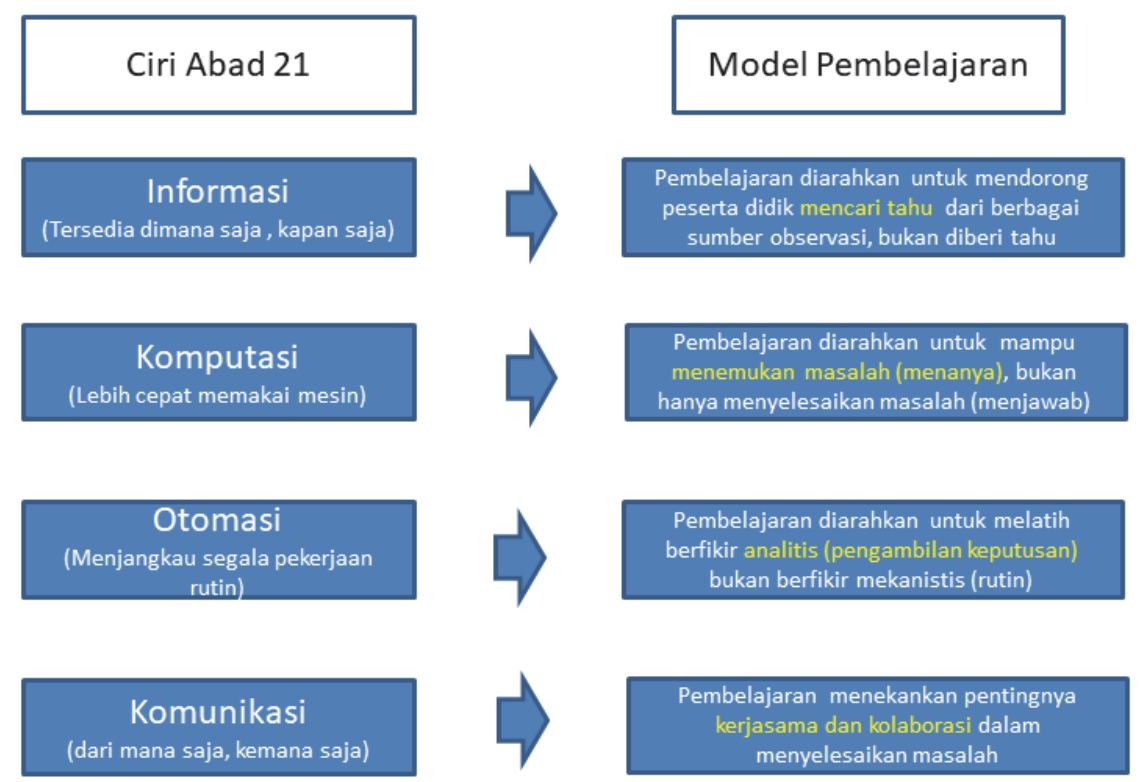

Gambar 3. Pergeseran paradigma abad 21

Sumber: (Wijaya, Sudjimat, dan Nyoto, 2016) 
Berdasarkan hasil wawancara diketahui bahwa subjek penelitian telah memiliki kemampuan untuk menganalisis dan mengevaluasi konten media khususnya yang berasal dari media digital meskipun belum secara komprehensif. Para subjek penelitian sudah mampu memahami konten dan fungsi media serta memanfaatkannya sebagai salah satu sumber informasi dalam kegiatan pembelajaran.

"Selain buku cetak, Youtube menjadi salah satu media yang saya manfaatkan dalam kegiatan pembelajaran. Upload tugas mahasiswa pada topik tertentu dan kemudian akan dinilai ketika tugas tersebut sudah ada di Youtube." (Subjek 2, wawancara 17 Juli 2018).

"Dalam topik pembahasan tertentu saya menggunakan Youtube sebagai sumber informasi, misalnya pada mata kuliah komunikasi massa, saya ambil video dari Youtube tentang the future of communication untuk menjadi bahan diskusi dalam kelas." (Subjek 3, wawancara 18 Juli 2018)

Di samping itu, pengetahuan tentang media juga sudah dimiliki oleh para subjek penelitian meskipun belum semuanya paham tentang regulasi media khususnya di Indonesia. Para subjek penelitian juga tidak selalu melakukan cross check sumber berita. Dengan adanya e-learning sebagai media pembelajaran digital kemampuan critical understanding akan terus meningkat. Dosen-dosen Program Studi Ilmu Komunikasi UNIDA Gontor dilatih untuk membuat konten-konten pembelajaran yang kreatif dan inovatif yang akan di upload di portal, tidak hanya sekedar "copy paste" dan memanfaatkan hasil karya orang lain. Berdasarkan hasil observasi diketahui bahwa kemampuan critical understanding subjek penelitian meningkat seiring dengan adanya e-learning di UNIDA Gontor.
Peneliti menemukan subjek penelitian mampu memanfaatkan e-learning tersebut untuk mempersiapkan materi yang lebih kreatif dan inovatif. Konten yang di upload lebih bervariasi seperti animasi, gambar, dan audio visual.

Temuan ini sejalan dengan hasil penelitian Barokati dan Annas tentang mata kuliah Pemrograman Komputer yang dijadikan sebagai salah satu uji coba pertama dalam implementasi e-learning (Barokati \& Annas, 2013). Hasil penelitian menunjukkan bahwa Mata kuliah Pemrograman Komputer yang telah diterapkan di UNIDA terdapat beberapa perbedaan yang lebih baik bila dibandingkan dengan sebelum implementasi e-learning. Temuan ini juga sejalan dengan penelitian Agustina yang bertujuan mengetahui pemanfaatan e-learning dalam pembelajaran dan faktor-faktor yang mempengaruhi di Universitas Bina Darma Palembang (Agustina, 2015). Hasil penelitian menunjukkan bahwa kondisi pemanfaatan e-learning sebagai media pembelajaran di Universitas Bina Darma berada pada kondisi cukup baik dengan tingkat presentase sebesar $60 \%$.

Kategori Individual Competence yang ketiga adalah Communicative Abilities atau kemampuan komunikasi yaitu kecakapan dalam mengkomunikasikan dan berpartisipasi melalui saluran media. Kemampuan komunikasi merupakan kecakapan dalam membangun hubungan sosial mau berpartisipasi dalam lingkungan melalui saluran media. Selain itu, kemampuan komunikasi juga meliputi kecakapan dalam menyusun konten/isi media. Adapun 
indikator communicative abilities terdiri dari update informasi di internet dan diskusi melalui forum di e-learning.

Berdasarkan hasil observasi ditemukan bahwa sebelum menggunakan dan memanfaatkane-learning kemampuan communicative abilities dalam proses pembelajaran belum dilakukan. Kemampuan komunikasi di internet terbatas pada kegiatan update status di media sosial yang tidak ada kaitannya dengan proses pembelajaran, melakukan kritik media sosial diluar materi pembelajaran, dan juga update berita dari internet untuk kepentingan peningkatan informasi untuk dirinya sendiri. Dengan adanya e-learning sebagai media pembelajaran virtual, kemampuan subjek penelitian dalam kriteria communicative abilities tentu akan meningkat.

Peningkatan communicative abilities terjadi karena kegiatan pembelajaran akan selalu menggunakan dan memanfaatkan internet. Hal ini sejalan dengan penelitian Adawi yang menyatakan bahwa dengan adanya aplikasi pendidikan jarak jauh yang berbasiskan komputer dan jaringan (internet, fax, fax-internet, dan lain-lain) maka ketergantungan akan jarak dan waktu yang diperlukan untuk pelaksanaan pendidikan akan dapat diatasi karena semua yang diperlukan akan dapat disediakan secara online sehingga dapat diakses kapan saja (Adawi, 2008).

Rujukan yang digunakan untuk mengetahui kemampuan dosen Program Studi Ilmu Komunikasi UNIDA Gontor dalam menggunakan dan memanfaatkan media digital didasarkan pada kriteria yang ditentukan Komisi Eropa Direktorat Jenderal Informasi Masyarakat dan Media; Unit
Literasi Media, selanjutnya dikonversi dan telah disesuaikan dengan kondisi social di Indonesia. Framework yang paling terkenal dalam peta konsep salah satunya adalah Individual Competence Framework. Individual Competence atau kompetensi individu adalah kecakapan individu untuk bermedia. Antara lain kecakapan to use, to produce, to analyze, to communicate melalui media.

Kompetensi individu ini terdiri dari dua kategoriyaitu:(1)Kompetensipersonal,yaitu kecakapan individu dalam menggunakan media dan menganalisis isi media. (2) Kompetensi Sosial, yaitu kecakapan individu dalam mengkomunikasikan dan membangun relasi sosial melalui media serta mampu memproduksi isi media.

Berdasarkan hasil analisis ditemukan sebuah model penguatan literasi digital yang disajikan dalam gambar 4 .

Gambar 4 merupakan model penguatan literasi digital di Universitas Darussalam Gontor yang dilakukan melalui proses pembelajaran. Komunikator yang terdiri dari para pengampu mata kuliah dasar menyampaikan pesan (konten pembelajaran) kepada komunikan (peserta kuliah) melalui media e-learning. Penggunaan media baru berupa e-learning dalam proses pembelajaran merupakan implementasi elemen communication and colaboration dalam literasi digital, di dalamnya terdapat komponen individual competence yang terdiri dari use skill, critical understanding, dan communicative abilities. Peningkatkan tiga komponen tersebut melalui pemanfaatan e-learning membuat kemampuan literasi digital komunikator akan semakin kuat. 


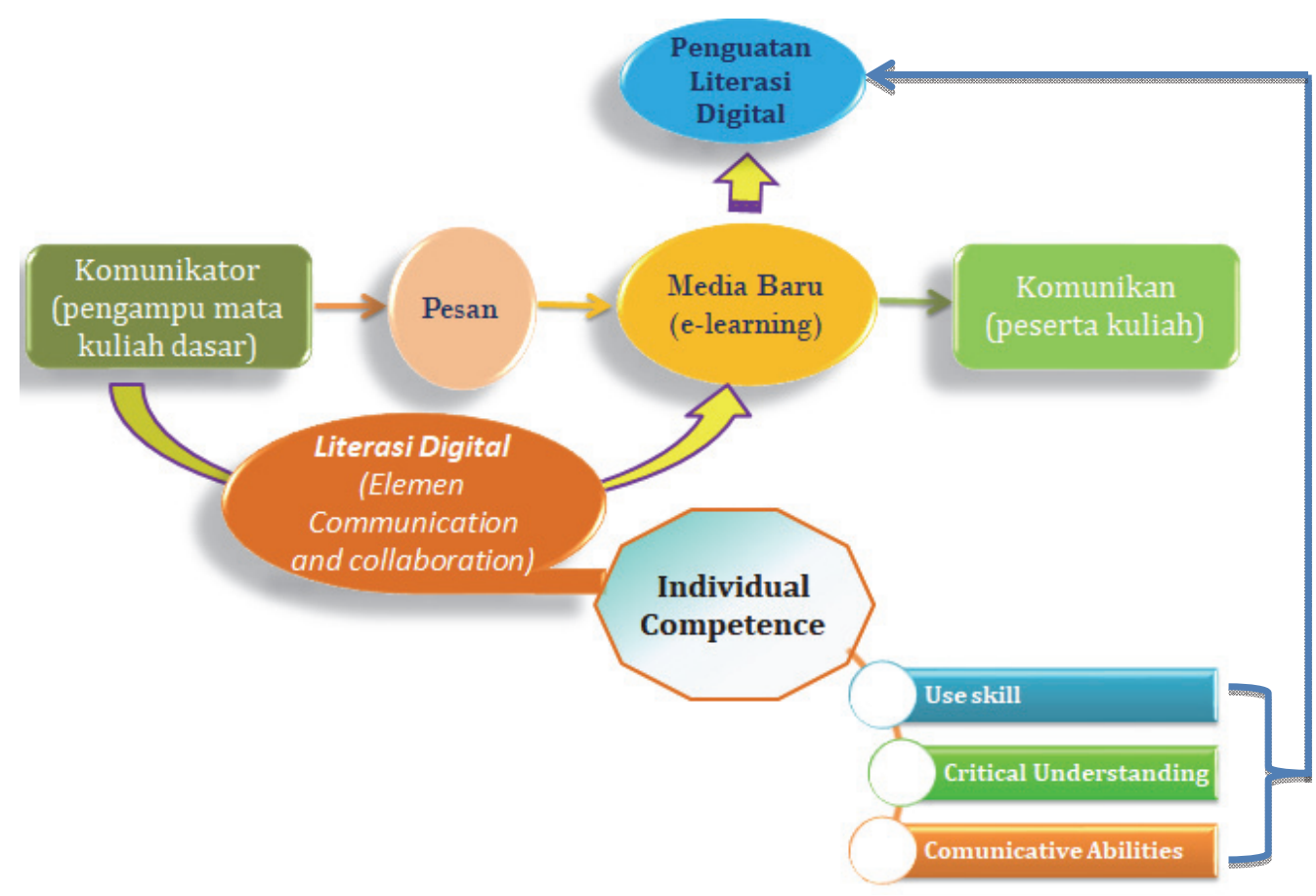

Gambar 4. Model Penguatan literasi digital melalui pemanfaatan e-learning

(Sumber: data peneliti 2018)

\section{Simpulan}

Penelitian ini menemukan sebuah model penguatan literasi digital di Universitas Darussalam Gontor. Penguatan literasi digital di Universitas Darussalam Gontor merupakan implementasi elemen communication and collaboration yang terdiri dari tiga komponen individual competence yaitu use skill, crirical understanding, dan communicative abilities. Communication and collaboration merupakan elemen literasi digital berupa partisipasi aktif dalam kegiatan pembelajaran yang dilakukan dengan memanfaatkan e-learning. Penggunaan e-learning dalam kegiatan pembelajaran di UNIDA Gontor menjadi salah satu model penguatan literasi digital. Adanya e-learning membuat para dosen pengampu mata kuliah dasar dituntut untuk menguasai media baru sehingga secara tidak langsung dapat meningkatkan individual skill literasi digital yang dimiliki. Kontribusi penelitian ini berupa model penguatan literasi digital melalui pemanfaatan e-learning di Universitas Darussalam Gontor. Penelitian tentang literasi digital di Universitas Darussalam Gontor perlu dilakukan untuk menganalisis enam elemen literasi digital lainnya. Rekomendasi penelitian juga ditujukan bagi pemangku kebijakan di UNIDA Gontor untuk memaksimalkan penggunaan e-learning sebagai salah satu upaya dalam penguatan literasi digital khususnya pada elemen communication and collaboration.

\section{Daftar Pustaka}

Adawi, R. (2008). Pembelajaran Berbasis E-Learning. Jurnal Bahas, (69TH XXXV), 1-12.

Adib, M. (2013). Ketika Pesantren Berjumpa Dengan Internet: Sebuah Refleksi Dalam Perspektif Cultural Lag. Jurnal Pusaka, 1(1), 1-10. 
Afandi, Junanto, T., \& Afriani, R. (2016). Implementasi Digital-Age Literacy dalam Pendidikan Abad 21 di Indonesia. In Prosiding Seminar Nasional Pendidikan Sains.

Agustina, M. (2015). Pemanfaatan E-Learning sebagai Media Pembelajaran. Seminar Nasional Aplikasi Teknologi Informasi (SNATI), 8-12.

Akbar, M. F., \& Dina, A. F. (2017). Teknologi Dalam Pendidikan : Literasi Digital Dan Self- Directed Learning Pada Mahasiswa Skripsi. Jurnal Indigenous, 2(1), 28-38. https://doi.org/10.23917/indigenous. v1i1.4458

Anggraini, S. (2016). Budaya Literasi Dalam Komunikasi. WACANA, XV(3), 181-279.

Bachri, B. S. (2010). Meyakinkan Validitas Data Melalui Triangulasi Pada Penelitian Kualitatif. Jurnal Teknologi Pendidikan, 10(1), 46-62.

Barokati, N., \& Annas, F. (2013). Blended Learning Pada Mata Kuliah Pemrograman Komputer (Studi Kasus: Unisda Lamongan). Jurnal SISFO: Inspirasi Profesional Sistem Informasi, 7(2). https:// doi.org/10.24089/j.sisfo.2013.09.006

Budhirianto, S. (2016). Model Pemberdayaan Relawan TIK Dalam Meningkatkan E-Literasi Masyarakat di Kota Sukabumi. Jurnal Penelitian Pos Dan Informatika, 6(1), 19-36. https://doi.org/10.17933/ jppi.2016.060102

Burkhardt, G., Monsour, M., Valdez, G., Gunn, C., Dawson, M., Lemke, C., ... Martin, C. (2003). enGauge 21st Century Skills: Literacy in the digital age. North Central Regional Educational Laboratory and the Metiri Group.

Chandrawati, S. R. (2010). Pemanfaatan E-Learning dalam pembelajaran. Jurnal Cakrawala Kependidikan, 8(2), 172-181.
Commission, F. the E., \& Unit, D. G. I. S. and M. M. L. (2009). Study on Assessment Criteria for Media Literacy Levels. Framework.

Damayanti, Maria Nala; Yuwono, E. C. (2013). Avatar, Identitas dalam Cyberspace. Jurnal Desain Komunikasi Visual Nirmana, 15(1), 13-18.

Darmayanti, T., Setiani, M. Y., \& Oetojo, B. (2007). E-Learning pada pendidikan jarak jauh: konsep yang mengubah metode pembelajaran di perguruan tinggi di Indonesia. Jurnal Pendidikan Terbuka Dan Jarak Jauh, 8(2), 99-113.

Hasugian, J. (2008). Urgensi Literasi Informasi dalam Kurikulum Berbasis Kompetensi di Perguruan Tinggi. Pustaka: Jurnal Studi Perpustakaan Dan Informasi, 4(2), 34-44.

Indonesia, A. P. J. I. (2016). Penetrasi dan Perilaku Pengguna Internet Indonesia. APJII.

JISC. (2017). Developing digital literacies | Jisc.

Kementerian Komunikasi dan Informatika Republik Indonesia. (2018). Siaran Pers No. 181/HM/KOMINFO/08/2018. Retrieved from https://kominfo.go.id/ content/detail/13943/siaran-pers-no181hmkominfo082018-tentang-literasidigital-siapkan-sdm-unggul-dancerdas-di-era-revolusi-industri-40/0/ siaran_pers

Kurnianingsih, I., Rosini, R., \& Ismayati, N. (2017). Upaya Peningkatan Kemampuan Literasi Digital Bagi Tenaga Perpustakaan Sekolah dan Guru di Wilayah Jakarta Pusat Melalui Pelatihan Literasi Informasi. Jurnal Pengabdian Kepada Masyarakat, 3(1), 61-76. https://doi.org/10.22146/jpkm.25370

Maksum, A. (2016). MODEL PENDIDIKAN TOLERANSI DI PESANTREN 
MODERN DAN SALAF. Jurnal

Pendidikan Agama Islam (Journal

of Islamic Education Studies), 3(1), 82-108.

Mardina, R. (2011). Potensi Digital Natives dalam Representasi Literasi Informasi Multimedia Berbasis WEB di Perguruan Tinggi. Jurnal Pustakawan Indonesia, 11(1), 5-14.

Piliang, Y. A. (2012). Mayarakat Informasi dan Digital: Teknologi Informasi dan Perubahan Sosial. Jurnal Sosioteknologi, 27(11), 143-156.

Rianto, P. (2016). Media Baru, Visi Khalayak Aktif dan Urgensi Literasi Media. Jurnal Komunikasi Ikatan Sarjana Komunikasi Indonesia, 1(2), 90-96.

Sholihah, K. (2016). Analisis Literasi Digital: Studi Pemanfaatan Jurnal Elektronik oleh Mahasiswa Magister Manajemen di Perpustakaan UKSW Salatiga. UIN Sunan Kalijaga Yogyakarta.

Stefani, S. N. B. (2017). Literasi Digital dan Pembukaan Diri: Studi Korelasi Penggunaan Media Sosial Pada Pelajar Remaja di Kota Medan. Sosioglobal, Jurnal Pemikiran Dan Penelitian Sosiologi,2(1), 10-31.

Sulianto, J. (2011). Keefektifan Model Pembelajaran Kontekstual dengan Pendekatan Open Ended dalam Aspek Penalaran dan Pemecahan Pada Materi
Segitiga di Kelas VII. Ilmu Pendidikan, 17(6), 454-458.

Susanti, E., \& Sholeh, M. (2008). RANCANG BANGUN APLIKASI E-LEARNING. Jurnal Teknologi, 1(1), 53-57.

Tamin, I. H. (2011). Peran Filantropi dalam Pengentasan Kemiskinan di dalam Komunitas Lokal. Jurnal Sosiologi Islam, 1(1), 35-58.

Trilling, B., \& Fadel, C. (2009). Learning Past and Future. In 21st century skills : learning for life in our times.

Umam, Kaiful; Zaini, I. (2013). Penerapan Media Digital Dalam Pembelajaran Apresiasi Batik Kelas X SMA Negeri 1 Blega. Jurnal Pendidikan Seni Rupa, 1(1), 100-105.

Widyastuti, D. A. R., Nuswantoro, R., \& Sidhi, T. A. P. (2016). Literasi Digital pada Perempuan Pelaku Usaha Produktif di Daerah Istimewa Yogyakarta. Jurnal ASPIKOM, 3(1), 1-15. https://doi. org/10.24329/aspikom.v3i1.95

Wijaya, E. Y., Sudjimat, D. A., \& Nyoto, A. (2016). Transformasi pendidikan abad 21 sebagai tuntutan pengembangan sumber daya manusia di era global. In Seminar Nasional Pendidikan Matematika 2016.

Yazdi, M. (2012). E-learning sebagai Media Pembelajaran Interaktif Berbasis teknologi Informasi. Jurnal Ilmua Foristek, 2(1), 143-152. 